\title{
„Napjainkra alakul az a szellemileg is felkészült csapat, amelyik kezdeményezője és befogadója a tudományos megközelítésnek..."
}

\begin{abstract}
A Belügyi Tudományos Tanács kezdeményezésére 2015 februárjában indult a Rendöri jelenlét a hátrányos helyzetü kistelepüléseken címü kutatási program. A vizsgálandó települések sorában találjuk a Gödöllői Rendőrkapitányság illetékességébe tartozó Bag nagyközséget. A felméréshez, amelyet a Nemzeti Közszolgálati Egyetem Rendészettudományi Karának oktatói végeznek, a Rendőrség Tudományos Tanácsa mellett jelentős segítséget nyújtott Gödöllő város rendőrkapitánya, $d r$. Bozsó Zoltán rendőr dandártábornok. A Belügyi Szemle szerkesztősége ezt az alkalmat kihasználva kért interjút a kapitánytól, akit a gyakorlat és a tudomány kapcsolatán túl a saját rendőri pályafutásáról és a beosztásával járó teendőiről is kérdeztünk.
\end{abstract}

\section{Bevezetésként arra kérjük, beszéljen a pályakezdéséröl!}

Bozsó Zoltán: Katonacsaládból származom, felmenőim két generációja is honvédségünkben szolgált, édesapám végül a büntetés-végrehajtástól ment nyugdíjba. Pályaválasztásomat döntően befolyásolta az otthoni háttér. Az érettségi után a Katonai Müszaki Föiskolán folytattam tanulmányaimat, és 1989-ben szereztem diplomát. Az első haderőreform idején kialakuló helyzetben a rendörség mellett döntöttem. Budapesten, illetve Pest megyében 1990 óta teljesítek szolgálatot, előbb a bünügyön, majd - köszönhetően katonai elöképzettségemnek - a közrendvédelem területén. Különböző beosztások után 2010-ben lettem Gödöllő rendőrkapitánya. Kapitányságunk kiemelt kategóriába tartozik, illetékességi területén huszonhét településen és nyolc városban csaknem kétszázezren laknak. Feladataink összevethetők akár egy kisebb megyéével is. A fóváros közelsége és a hely történelmi szelleme még tovább gyarapítja teendőinket. 2011-ben például, amikor hazánk töltötte be az Európai Unió elnöki tisztét, a nemzetközi jelentőségü események jelentős része városunkban zajlott. Mogyoród és benne a Forma-1-es versenypálya visszatérö próbatétel, különösen az idén, amikor a Hungaroring a harmincadik évfordulóját ünnepli. Noha már huszonöt esztendőnyi szolgálat áll mögöttem, a tanulással nem hagyok fel. A Rendőrtiszti Főiskola bünügyi szakát is beleértve, öt 
diploma megszerzése, továbbá két nyelv elsajátítása mellett a nemrég megalakult Nemzeti Közszolgálati Egyetem Hadtudományi Doktori Iskolájában az elsők között kaptam PhD-fokozatot rendőrségi szervezéstanból. Doktori kutatási területem a rendörségi vezetéselmélet és ügyeleti rendszerek, különös tekintettel a rendezvénybiztosításra. Megjegyzem, hogy ez a téma inkább a rendészettudományi kar most alakulóban lévő doktori iskolájához illene, de amikor én védtem, akkor az még nem müködött.

- A Rendörség Tudományos Tanácsának tagjaként miként látja a tudományok és a gyakorlat kapcsolatát?

B. Z.: Az elmélethez a kilencvenes évek közepétől fordultam nagyobb figyelemmel, amikor a megyei fókapitányságokon kialakult a tudományos referensek rendszere. Korábban azt tapasztaltam, hogy a kutatások iránti érdeklődés meglehetősen hullámzó volt, időnként ilyen igényességet alig lehetett tapasztalni. Napjainkra alakul az a szellemileg is felkészült csapat, amelyik kezdeményezője és befogadója a tudományos megközelítésnek, ezt jelentösen serkeni az országos vezetés támogatása. Ez abban is kifejezésre jut, hogy újabban komolyan elismerik azoknak a teljesítményét, akik a munka mellett szereznek tudományos fokozatot. Mind a belügyi, mind pedig a rendőrségi vezetés igényli a távlatos gondolkodást, annak előre vetítését, hogy a stratégiai jelentőségű feladataink miként alakulnak öt vagy akár tíz esztendő múlva. Ehhez tudományos felkészültségre van szükség.

【 A katonai múltja arra késztet, hogy megkérdezzük: miként vélekedik a hadtudományi, a rendészettudományi és a közigazgatás-tudományi karok integrációjáról?

B. Z.: A kezdeményezést jónak tartom, a kivitelezés pedig számomra azt vetíti elöre, hogy ebben az összeállításban a rendészettudománynak kell a vezető szerepet vállalnia. Nem kétséges, hogy a legnagyobb létszámú, a legszínesebb tagozati struktúrát felmutató karról van szó, a túljelentkezés aránya itt a legmagasabb. Az egykori Rendőrtiszti Főiskola nyilván nagyobb önállósággal müködött, a jelenlegi integrációban sokféle érdeket kell egyeztetni, de az új egyetem a magasabb szintü teljesítmény lehetőségét hordja magában. Azt is figyelembe kell venni, hogy a Rendőrtiszti Főiskola nagy hagyományokkal büszkélkedhetett, a hazai rendészet legkiválóbb szakemberei ott alapozták meg tudásukat. A fejlődés irányát jól mutatja az egyetemi végzettséget nyújtó mesterképzés, ahol több középvezetői posztot betöltő kollégám végzett, illetve tanul jelenleg. Ök elmondják, hogy a kétéves kurzuson jól hasznosítható és 
komoly elméleti megalapozást lehetővé tevő tudás átadása történik, a szakmában elismert, hiteles oktatók által. A szak egyre népszerübb lesz, amit jelez az évfolyamok állandóan növekvő létszáma. A tudomány szerepéről már szóltam. Az új egyetemi kar hozzájárulhat a rendészettudomány további erősödéséhez. Megszünik az a kényszerítő helyzet, amelyben a rendőrségi kutatások jelentős része a hadtudományok gondozásába került. Abban a doktori iskolában, amelybe én jártam, a tizenkét hallgató között egyedül voltam rendőr. A jövőben a rendészettudományi doktori iskola válhat a rendészeti kutatások szakmai mühelyévé, ehhez az egyetemmé válás egyengette az utat.

【 Miként alakul a kapitányság illetékességi területén a bünügyi helyzet, és általában a közbiztonság?

B. Z.: A bünügyi helyzet értékelésében is fontos szerepe van a főváros közelségének, az egyre javuló közlekedési adottságoknak (M0, kitünő tömegközlekedés, kapcsolat a Liszt Ferenc repülőtérrel stb.). Az említett illetékességi terület csaknem fele Budapest agglomerációjának a része. Pest megyének nincs megyeszékhelye, de a vezető szerepet Gödöllő tölti be. A büncselekmények száma nálunk az elmúlt négy-öt évben folyamatosan csökkent, ezt alátámasztják azok a közvélemény-kutatások, amelyeket részben a Belügyminisztérium maga végzett, részben pedig kutatóintézetektől rendelt meg. $\mathrm{E}$ lakossági kikérdezések eredménye szerint a szubjektív biztonságérzet is jelentősen javult ebben az időszakban. Beszédesek azok a számok, amelyek szerint az elmúlt valamivel több mint négy évben területünk összbünözése csaknem felére csökkent. A javulásnak csak kisebb része magyarázható a jogszabályváltozásokkal (például a szabálysértési értékhatár növekedésével), a közbiztonság megerősödését azonban elsősorban a rendőri jelenlét fokozásával, a felderítési eredményesség emelésével értük el. Mindehhez hozzájárult az is, hogy számos önkormányzat pályázati úton lehetőséget kapott térfigyelö kamerák telepítésére és arra, hogy helyi közterület-felügyeleti szerveket müködtessen. Szemléletváltást tükrözött a rendőri létszám emelése. A mi rendőrkapitányságunk esetében négy év alatt százzal gyarapodott az állomány. A korábbi kétszázas létszámhoz képest egyharmaddal nőtt a rendelkezésre álló rendőri erö.

【 A létszámemelés kritikusai szerint az újonnan felvettek gyengébb kiképzést kaptak. Erröl milyen tapasztalatai vannak?

B. Z.: Én nem a képzettségben látom a problémát. Valamennyien elvégezték a rendészeti szakközépiskolát, és a kétéves képzés felét már nálunk a gyakor- 
latban töltötték el. A korosztályom és a nálam idősebbek azonban még hivatásnak tekintik ezt a pályát, azt is mondhatnám, hogy elhivatottsággal jellemezhetö életformának, míg a most kezdök többsége inkább munkahelynek gondolja, egynek a sok közül, amit könnyebben el is hagynak, ha személyes körülményeik úgy alakulnak.

【 Készül az új szolgálati törvény, és ezzel kapcsolatban vannak aggodalmak, miszerint növekednek a szolgálati kötöttségek, emlékeztetve az 1990 elötti időkre. Igazuk lehet az aggódóknak?

B. Z.: Azt gondolom, hogy figyelmesen el kellene olvasni a több száz oldalas tervezetet, és akkor a kritikusok nem mondanának ilyeneket. Azt tudomásul kell venni, hogy ennek a szakmának a világon mindenhol vannak kötöttségei, amelyekkel akkor kell megismerkedni, amikor valaki hozzánk jelentkezik. A hivatással járó kötelmek önkéntes vállalásával sok későbbi konfliktus megelőzhető.

- Csaknem huszonöt évvel ezelött a magyar rendörséget tanulmányozó külföldi szakemberek maguk is hangoztatták a rendöri pályával járó kötöttségeket, de arra figyelmeztettek, hogy egy modern rendörségnél ezt kompenzálja a magasabb jövedelem, valamint a biztonságot nyújtó életpálya. „Biztonságot csak az a rendör képes szolgáltatni, aki maga is biztonságban van”, idézték az európai rendörszakszervezetek egyik jelszavát. Mi hogyan állunk e téren?

B. Z.: A készülő jogi szabályozás nem csupán azzal növeli a pálya átláthatóságát, hogy a jogszabályok tömegét egyetlen szabályozás váltja fel, hanem azzal is, hogy a belépéstől a nyugdíjazásig, sőt azon túl is láthatóvá és kiszámíthatóvá válik a hivatásos szolgálatot vállaló jövője. Az nem elfogadható, hogy a negyvenes éveikben járó szakemberek elött nyíljon meg a nyugdíj lehetősége. A tervek szerint a kiemelt bérezés lesz hivatva anyagilag is elismerni a többletterheket. A követelmények azonban egyre szigorúbbak. Aki nálunk akar egy szakmai utat bejárni, annak folyamatosan képeznie kell magát. Amikor az életpályánkat tervezzük, ezzel is számolni kell, de egyben ez lesz a jobb teljesítmények garanciája. Tőlünk a társadalom is ezt igényli, és a rendőri intézkedések szakszerüségének a kulcsa is valahol itt található.

I Régóta vita folyik az önkormányzati rendörség lehetöségéröl. A decentralizálást már huszonöt évvel ezelött elvetették, és azóta sem gyengült az államrendörségi modell támogatottsága, szemben bizonyos kutatói véleményekkel. Ön hogyan vélekedik erröl? 
B. Z.: Én az indokolatlanul bonyolult szervezeti megoldásokat tartom gondnak. Számos nyugat-európai országban egyszerübb, áttekinthetőbb szervezeti megoldásokat alkalmaznak. Az arányokra jellemző, hogy Budapesten és Pest megyében történik a büncselekmények negyven százaléka és itt él az ország lakosságának egyharmada. Van olyan megye, ahol a büncselekmények száma és a lakosság aránya közel azonos a mi kapitányságunk adataival, a rendőri létszám viszont a miénknek a háromszorosa. A centralizáltságot azonban nem enyhíteném, hanem annak az előnyeit kihasználva gondolkodnék a struktúrán. Amikor az erök gyors koncentrációjára van szükség, természeti csapások, árvizek a jó példák erre, a leghatásosabban a centrumból irányított rendőrség tud gyorsan és szakszerüen reagálni. Rendőrségünk közigazgatási szervezetében a megyei szintet azonban, éppen a vármegyerendszer mély történelmi hagyományaira tekintettel, érdemes megőrizni. Ami pedig a hazai hagyományokat illeti, nálunk a modern jogállami rendőrség követelményeinek kezdetektől az államrendőrség volt képes megfelelni. Ezen a területen az önkormányzatiságnak nincsenek történelmi gyökerei. Ellentétben néhány szomszédunkkal, például Szlovákiát említhetem, ahol van önkormányzati rendőrség, de ennek a hagyományai is megvannak.

【 Az új önkormányzati törvény szélesebbre tárta az autonómiák lehetőségét a helyi közbiztonságot szolgáló önkormányzati szervezetek létrehozásában. Tapasztalható-e ezen a területen változás?

B. Z.: Ezen a területen nagyon tarka a kép. Van, ahol közterület-felügyelet, máshol városőrség vagy helyi rendészet müködik, és van, ahol nem hoztak létre ilyen egységeket. Az új törvényi lehetőséggel több településen éltek, így például Gödöllő városában is, de egységes gyakorlatról országos szinten nem beszélhetünk. Mindamellett a polgárör mozgalom jelenléte erősen érzékelhető, ami erős támogatás a helyi közbiztonság megörzésében.

【 A bevezetöben szóltunk arról a kutatásról, amely a hátrányos helyzetü kistelepülések rendöri ellátottságát hivatott vizsgálni. Összhangban az ön értékelésével, az országos rendöri vezetés - a Rendörség Tudományos Tanácsával karöltve -jelentös támogatást nyújt ehhez a munkához. Az önök területén Bag községre esett a választás. Egyetért ezzel a mintavétellel?

B. Z.: Ennek a településnek rosszabb a híre, mint a valós helyzete. Mintegy négyezren lakják, a településen korábban jellemző kisebbségi létből adódó kulturális különbségek enyhültek. Ötéves visszatekintésben itt is csaknem a felére csökkent a büncselekmények száma. Kapitányságunk területén ezer la- 
kosra megközelítően tizennyolc büncselekmény jut, Bagon ez a szám negyven, de a szint, ahonnan indultunk, hetven volt. Bagnak van körzeti megbízottja, van telepített térfigyelö rendszer, és müködik a helyi polgárör szervezet is.

【 Hogyan alakul a kapitányság területén a rendörsürüség, az egy rendörre jutó lakosok száma?

B. Z.: Az országos és a megyei átlagtól eltérően a mi rendőrkapitányságunk területén úgy hétszáz körül alakul. Ugyanakkor a megye tizenhárom rendörkapitánysága közül a büncselekmények aránya nálunk a legkedvezőbb. Ezt a jó eredményt rosszabb létszámarányokkal érjük el, ami csak úgy lehetséges, hogy a szolgálatszervezésben vagyunk körültekintők, de a kollégák jobb teljesítménye is szükséges ennek a kedvező helyzetnek a megőrzéséhez. A rendőrkapitányságok tagoltságáról már szóltam. Jellemzö, hogy van hetven- és van ötszáz fös rendőrkapitányság. A kedvezöbb arányokat a rendőrőrsök észszerü kialakítása is segítheti. Például a hatvanas években Aszódon még kapitányság müködött, most ott egy rendőrörs van, amelynek illetékességébe Bag is beletartozik. A rendőrörs megoldást hozhat, ha annak megfelelő létszámú és felkészült az állománya, valamint a technikai ellátottsága is kielégítő. A járások visszaállításával Aszód járási székhellyé vált, ezért ott a rendőrőrs is kiemelt kategóriába került. Van két alosztálya, egy rendészeti és egy bünügyi.

- Több év óta gyakorlat, hogy egyes településeken a rendöri jelenlétet a Készenléti Rendörségtöl vezényelt állomány erösiti. Erre van példa Gödöllön is? B. Z.: A Készenléti Rendőrségnek rugalmas, mozgatható egységei vannak, ezért tudnak segíteni ott, ahol létszámproblémákra, vagy éppenséggel a helyi közbiztonságot veszélyeztető konfliktusokra kell reagálni. Ilyen segítséget mi is igényeltünk. Korábban például Bagon alakult ki olyan feszültség a lakosság körében, hogy indokolt volt a huszonnégy órás rendőri jelenlét. A Készenléti Rendőrségről ide vezényelt állomány eligazitását és irányítását mi végezzük, és a szolgálatban a helyi erők is részt vesznek. Ez biztosítja az ilyen feladatok végrehajtásához nélkülözhetetlen helyismeretet. Az együttmüködés eredményességét igazolja, hogy miután két évvel ezelőtt a készenlétiek csaknem háromezer munkaórát teljesítettek nálunk, az említett helyi konfliktusokat a jól szervezett jelenléttel sikerült konszolidálni, és ez Bagon is a nyugalmat hozta el az ott élők számára.

- Most folyik a büntetóeljárási törvény újrakodifikálása. Bünügyi tapasztalataira utalva kérdezzük, miként látja az elökészitö eljárásban a felderités, nyo- 
mozás és a vizsgálat elkülönülését, ami a jövöbeni szabályozást is befolyásolhatja.

B. Z.: A tapasztalataim szerint a felderítés és a nyomozás szorosan összetartozó folyamatok, ami döntően terepmunka, ezt a szervezetnek és a szabályozásnak is tükröznie kell. A bünügyi technika ettől elválik, külön szakterületként müködik együtt a nyomozással. Az elkövető kézre kerítése utáni vizsgálat azonban inkább irodai tevékenység, annak külön szervezetben tartása indokolt, és ezt a készülő eljárási törvénynek is figyelembe kell vennie. Ez a tagoltság az ügyészi felügyeletben is felismerhető, az ügyész rendelkezési joga sokkal erőteljesebb a vizsgálati szakaszban, mint a nyomozás során.

— Térjünk vissza a beszélgetés vezetö témájához! A rendörségi törvény elöirja a kapitányságok beszámoltatását az önkormányzati testületek elött. Miként alakul ez a gyakorlat?

B. Z.: Ezeket a beszámolókat az önkormányzatok is igénylik. Az együttmüködés napi gyakorlattá vált, számos fórum ad alkalmat a kölcsönös tájékoztatásra, ezért az éves beszámoltatás formálissá vált. Jellemző, hogy az elmúlt négy évben valamennyi beszámolónkat ellenszavazat nélkül fogadták el az önkormányzati testületek. Van olyan külföldi példa, ahol formális beszámoltatás nincs, ellenben a helyi lakosok rendszeres kikérdezésével tájékozódnak a rendőrség munkájáról kialakult közvélekedésről. Amit azonban mindennél fontosabbnak tartok, az a rendörség és a közbiztonságban érdekelt önkormányzati és civil szervezetekkel való folyamatos együttmüködés. Ebben a legutóbbi időszakban minőségi javulást érzékelek. Jellemző, hogy hosszú évek óta elöször a tavalyi országgyülési választás kampányában nem került előtérbe a közbiztonság kérdése, minthogy a közösségek nem sorolták a leginkább égető problémák közé. Ez fontos és jó jelzés a mi munkánkról is.

Készítette: Finszter Géza 